\title{
Toplumsal Değişimin Bir Faktörü Olarak Turizm
}

\author{
Tourism as a Factor of Social Change \\ Ertan ÇAKMAKCI* \\ Şinasi ÖZTÜRK**
}

\author{
* Öğr. Gör. Dr. Muğla Sttkı Koçman Üniversitesi, Milas MYO, ertan.cakmakci48@gmail.com \\ **Doç. Dr. Muğla Sıtkı Koçman Üniversitesi, Edebiyat Fakültesi, Sosyoloji Bölümü, sinasiozt@gmail.com \\ ORCID Numarası I ORCID Number: *0000-0002-7019-3704 - **0000-0002-9393-7163
}

\begin{abstract}
Öz: Turizmin ekonomik, sosyal ve kültürel bir olgu olması, turizm faaliyetlerinin gerçekleștiği yörelerde birtakım ekonomik, sosyal ve kültürel değişimlerin oluşmasına yol açabilmektedir. Esasen bir toplumda her zaman, her şey değişmektedir. Değişimin hızı veya hangi alanlarda yoğunlaştığı, değişime etki eden faktörlerin hangisinin daha önemli rol oynadığına bağlıdır. Bu anlamda turizm belli yörelerdeki değişimin yönünü ve hızını belirleyebilecek bir katalizör görevi görebilir. Bu çalışmada, turizmin yörede yaşayan insanların ekonomik, sosyal ve kültürel yaşamları üzerine etkileri kavramsal çerçevede ve ayrıca bu yörelerin nüfus hareketlerinin turizm gelirine bağlı olarak artışı istatistiki olarak incelenmiştir. Çalışmada ikincil veri kaynakları kullanılmıştır ve turizmin yörelerde ekonomik kalkınmaya paralel olarak nüfus artışına ve yörenin sosyal ve kültürel yapısında değişime neden olduğu sonucuna ulaşılmıştır.
\end{abstract}

Anahtar Kelimeler: Ekonomi, kültür, toplumsal değişim, turizm.

Abstract: The fact that tourism is an economic, social and cultural phenomenon may cause some economic, social and cultural changes in the regions where tourism activities take place. Essentially in a society, always everything changes. The speed of change or in which areas it is concentrated depends on which factors play a more important role. In this sense, tourism can serve as a catalyst to determine the direction and speed of change in certain regions. In this study, the effects of tourism on the economic, social and cultural lives of the people living in the region were analyzed in a conceptual framework as well as the increase of population movements of these regions depending on tourism income. In the study, secondary data sources are used and it is concluded that tourism causes changes in population and social and cultural structure of the region in parallel with economic development in regions.

Keywords: Culture, economy, social change, tourism. 


\section{Giriş}

Toplumsal değişim, toplumun kültürel, sosyal ve ekonomik yapısındaki değişimleri ifade eder. Değişim, değişime neden olan çok çeşitli faktörlerin bir bileşkesidir. Bu anlamda, turizmin bir yörede meydana getirebileceği değişim, turizmin etki ettiği alanlar ve ilişkiler temelinde düşünülmelidir. Turizmin turistik yöre üzerine olan ekonomik, çevresel, kültürel ve sosyal etkileri, yörenin toplumsal olarak değişiminin önemli bir faktörü niteliğindedir. Değişimi diğer bazı koşullarla birlikte hızlandıran bir etkiye sahip olan turizm, özellikle yöredeki üretim ilişkilerini ve sosyal yaşam pratiklerini değiştirme ve dönüştürme kapasitesine sahiptir. Ekonomik kalkınma gibi bir kısım etkiler, turizmin olumlu etkileri olarak ortaya çıkarken, yörenin kültürel değerlerinin erozyona uğraması (bazen de kültürel değerlerin korunmasının ön plana çıkarılması) ve sosyal yaşamda yöre sakinlerinin huzurunu bozacak şekilde kalabalıklaşma, aile düzeninde bozulmalar gibi olumsuz etkileri ortaya çıkabilmektedir. Bu çalışmanın amacı, turizmin yöreye etkilerinin ekonomik, sosyal, kültürel ve çevresel faktörler üzerinden değerlendirmesini yapmaktır.

Giddens'a (2008) göre toplumsal değişmeyi tanımlamak zordur. Çünkü bir anlamda her zaman, her şey değişmektedir. Önemli değişimi belirlemek, bir nesne ya da durumun temel yapısında bir dönem içerisinde ne kadarlık bir değişme ortaya çıktığını göstermeyi gerektirir. İnsan toplulukları söz konusu olduğunda, bir sistemin hangi ölçüde ve hangi bakımlardan bir değişme süreci içinde olduğuna karar verebilmek için, belirli bir özgül dönem içerisinde temel kurumlarda hangi ölçüye kadar değişiklikler ortaya çıktığını göstermek gereklidir. Giddens, toplumsal değişmeyi üç etkene bağlamaktadır. Bunlar; fiziksel çevre, politik örgüt ve kültürel etkenlerdir. Fiziksel çevrenin toplumsal değişim üzerine etkisini hava koşullarının yaşam biçimi üzerine etkisi üzerinden ele almaktadır. Ona göre, farklı iklim bölgelerinde yaşayanlar farklı alışkanlıklar ve pratikler geliştirirler. Siyasal örgüt modern dünyada, ekonomik olarak büyüme gösteren durumlara müdahale etme ve onu yönetme işlevini toplum nezdinde yürütmektedir. Giddens, kültürel etkenler olarak ise, toplumsal ve politik değişim süreçlerinin gelenekçi yapılara bağlanamayacağını ve bu yüzden modern dönemde insanın daha iyiye gitmek için, yaşam biçimlerini sürekli gözden geçirmesinin gerekliliğine işaret etmektedir (Giddens, 2008,77-83).

Toplumsal değişme, toplumu oluşturan bireyler arası ilişkiler ve bu ilişkiler neticesinde ortaya çıkan toplumsal yapıdaki değişmelerdir. Değişme, belli bir toplumun sınırları altında ele alınarak değerlendirilmektedir. İlişkisel olarak toplumsal değişim anlayışı ile toplumsal, kültürel ve siyasal değişme arasında bir fark yoktur. Çünkü hangi yapı olursa olsun, bir toplumda kültürel ve siyasal yapıyı belirleyen unsur insan ilişkileridir (Kongar, 2010: 56). Bir sosyal sistem ve onu oluşturan kurumlar, birbirleriyle irtibatlı, gizli ittifaklar yapan ve birbiriyle çatışan geniş çeşitlilikte grupların merkezindedir. Wallerstein (2010), toplumun bir araya getirilmiş parçalardan daha fazlası olduğunu iddia etmektedir. Ona göre sosyal yapılar insan ilişkilerinin mercan kayalıklarıdır. Toplum, uzun zaman dilimleri boyunca kalıcı ve sağlam karakterli değerler oluşturur (Wallerstein, 2010: 21-29). Bu yüzden bir toplumdaki değişimi anlamak zordur.

Toplumsal değişimi konu alan kuramların içerisinde turizmin doğrudan etkisini ele alan bir yaklaşım yoktur. Esasen turizm ekonomik girdi üzerinden yarattığı etki bakımından yörenin sosyal ve kültürel yapısı üzerinde de etkiler yaratabilmektedir. Turizmin toplumsal değişime doğrudan bir etkisinin ne kadar olduğu veya olup olmadığı tartışmalı bir konudur. Ancak turizmin insanlar arası ilişkilerin yoğun bir şekilde yaşandığı ve kültürel yapıların iç içe bir şekilde temas halinde olduğu düşünüldüğünde, bu ilişkinin yarattığı toplumsal bir örüntü biçimi ve yapının ortaya çıkması muhtemeldir. Turizm, başta ekonomik olarak toplum üzerinde bir etki yaratır ki, bu etki diğer ilişkilerin ortaya çıkmasının öncüsü olur. Başka bir deyişle, turizme katılımın ana katalizörü ekonomik beklentilerdir ve sonrasında yaşanan etkiler bunun bir sonucudur. 
Turizm ile birlikte bir yörede üretim ilişkilerinin değiştiği, yeni istihdam olanakları ile birlikte yörede yaşayanların gelir seviyelerinde artışlar olduğu ve tarımdan endüstriye geçişin (Aykaç, 2009: $105)$ ve buna ait ilişkilerin yaşandığ bir toplum yapısı ortaya çıkmaktadır.

Endüstrinin yayılması fiziksel çevre, kültür ve insan üzerine ciddi etkiler yaratabilmektedir. Bu etkilerin turizm kaynaklı faaliyetlerin bir sonucu olarak toplum üzerine etkileri bu araştırma ile tartışılmıştır. Çalışmada Muğla'nın turizm merkezleri olan Bodrum, Marmaris ve Fethiye'nin gelişimi ve değişimi, diğer turizm merkezi olmayan ve kısmi turistik ilçelerle karşılaştırma yapmak suretiyle ikincil veri kaynakları kullanılarak incelenmiştir. Kültürel ve sosyal yapı üzerine etkileri, yıllara göre nasıl bir değişim gösterdiğine ilişkin olarak kayıtların yetersizliği nedeniyle kavramsal çerçevede ele alınmıştır. Muğla ili ve ilçelerinin turizm ile birlikte yıllar içindeki gelişimi ekonomik ve demografik boyutlardan tablolar ve grafikler halinde gösterilmiş ve turizmin gelişiminin nüfus üzerine etkileri regresyon analizi yardımıyla ortaya konmuştur.

\section{Turizmin Sosyal, Kültürel Ve Ekonomik Değişime Etkilerinin Kavramsal Boyutta Değerlendirilmesi}

Turizm 1980'ler ve 1990'lar boyunca dünya çapında en hızlı büyüyen sektörlerden biri olmuştur (Biagi, Brandano ve Detotto, 2012: 2). Bu durum küreselleşme olgusuyla paralellik arz eder. Turizmin bu hızlı gelişimi özellikle çevre ve yarı çevre ülkelerde önemli dönüşümler yaratmıştır (Aykaç, 2009: 13). Aykaç, üretim ilişkileri bakımından turizm yörelerinde yaşayan halkın bir işçileşme süreci içine girdiğini ifade etmektedir. Daha önce tarım ve hayvancılıkla uğraşan yöre insanın bir kısmı, turizmin yarattığı geniş istihdam olanakları sayesinde çoğunlukla kendi toprağı üzerinde üretim yapan köylü ya da çiftçi olarak adlandırılan bir konumdan işçi konumuna bir değişimi yaşamıştır.

Turizm, tüketicilerin ürünü satın almak için seyahat ettikleri bir ihracat endüstrisi olarak benzersizdir (Crick, 1989: 310'den Aktaran Brunt ve Courtney, 1999: 495 ). Uluslararas1 turizmin yaygınlaşması, farklı toplumlar ve kültürler arasındaki temayı artırmıştır. Bazıları için bu etkileşim geleneksel kültürü ve toplumu yok etmek için bir tehdit, bazıları için ise uluslararası barış, anlayış ve daha fazla bilgi için bir firsat olarak bulunur. Bu tür sosyal etkiler hem turistler hem de ev sahibi toplumlar üzerinde yaşam kaliteleri açısından daha doğrudan bir etkiye sahip unsurlar olarak tanımlanabilir (Brunt ve Courtney, 1999: 495).

Turizm gibi hizmetler, özellikle kırsal alanlarda, ekonomin durgunluk dönemlerinde toplulukların desteklenmesine yardımcı olan ekonomik bir "amortisör" işlevi görmektedir (Dičevska ve Simončeska, 2012:280). Turizm, bölgelerarası gelir adaletsizliğinin giderilmesi, göç sorunu, alt yap1 olanaklarının geliştirilmesi ve kırsal kalkınma açısından yöre insanına ciddi avantajlar sunmaktadır (Çeken, 2008: 303). Akis (2011), turizmin birçok sektörü etkilediğini ve yeni sektörlerin oluşumuna katkıda bulunduğunu ve yörenin alt yapı sorunlarının böylece giderilebildiğini belirtmektedir. Ancak, Akis'e göre, turizm faaliyetlerinin yaygınlaşması, trafik ve kirlilik, doğal çevrenin ve kıyı şeridinin zarar görmesi gibi çevresel sorunlara yol açabilmektedir. Bu yüzden sürdürülebilir bir gelişme sağlayabilmek için yerel otoritelerin ve turizm sektörünün konuya özenle yaklaşmaları önemlidir (Akis, 2011: 296).

Farklı gruplar farklı turizm etkileri hakkında endişe duymaktadırlar. Bir grup, turizmin ekonomik etkilerini benimsediğinde başka bir grup sosyal ve kültürel etkiler yaşar; bir diğeri ise turizmin çevresel etkilerinden etkilenir. Birinci gruptakiler iş dünyasını ve turizm tarafından sunulan işlere muhtaç insanları içerebilir. İkinci gruptakiler, ziyaretçi akını nedeniyle kendini yerinden olmuş hisseden sakinleri içerebilir. Üçüncü gruptakiler, doğal kaynaklar konusunda endişe duyan yerel doğaseverleri oluşturabilir. Böyle bir durumda her grubun turizm hakkında farklı görüşleri olacaktır. İdeal olarak, tüm 
gruplar olumlu olarak etkilendiği ölçüde turizme yönelik çabalar desteklenecektir. Fakat grup çıkarları farklı olduğunda farklı perspektifler turizmin gelişiminde fikir birliği sağlanmasını zorlaştırır (Kreag, 2001: 3-4).

Turizm, kadınlar ve gençler için istihdam olanakları sunmaktadır. Sektörde, diğer sektörlere nazaran kadınlar için daha fazla iş imkânı vardır. Turizmde çok farklı sosyo-ekonomik ve sosyo-kültürel gruplardan insanlar aynı işletme içinde çalışabilmektedir (Şit, 2016: 107). Turizmde ortaya çıkan işlerin kadın işi - erkek işi olarak ayrıma tabi tutulması, cinsiyet temelli bir yaklaşımı gündeme getirir. $\mathrm{Bu}$ yaklaşım içerisinde kadınların, geleneksel toplum yapısı içerisinde kadına biçilen roller kapsamında temizlik, bakım ve yeme-içme hazırlıkları gibi işlerde yoğunlaştığı görülür. Yine küçük aile işletmeleri şeklindeki pansiyonlara bakıldığında, kadının rolünün temizlik ve yeme içme işlerine hazırlık işleri, erkeklerin ise daha çok paranın kontrolünü sağladığı ișler ile uğraștığı görülür. Bununla beraber, kadınların ücretli bir işe ulaşmalarında turizm sektörünün sağladığı potansiyel, toplumsal cinsiyet eşitliğinin gerçekleştirilmesi ve kadının güçlendirilmesi için, Birleşmiş Milletler Kadın Örgütü ve Uluslararası Çalışma Örgütü gibi kurumların odağında yer alır (Kaya, 2017: 3-4).

Turizm, yöredeki alt yapı ve üst yapı olanaklarının gelişmesini ve yöre halkının bu hizmetlere ulaşımını kolaylaştıran ekonomik etkilere sahiptir (Kreag, 2001: 6-7). Gürbüz (2002), turizmin ortaya çıkardığı ekonomik etkinin halkın yaşam seviyesine olumlu katkısı nedeniyle, ortaya çıkan sosyal etkinin olumsuz sonuçlarının görünmesini engellediğini ya da bunun olumlu ekonomik etkiler nedeniyle tolere edildiğini belirtmektedir. Ayrıca, turizmin küçük yerleşim yerlerinde aile içi iletişim bozukluğu, gelenek-göreneklerde değişiklik, dini sorunlar ve kültürel yönde değişimlere yol açtığını ifade etmektedir (Gürbüz, 2002: 58).

Turizm, tarihi binaları ve anıtları korumayı ve restore etmeyi mümkün kılar. Turizm, genellikle fabrikalar yerine otellere, restoranlara, mağazalara ve cazibe merkezlerine dayanan "temiz" bir endüstri olarak kabul edilir. Turizm bir çevreyi bozabilir de. Ziyaretçiler atık ve kirlilik yaratır (hava, su, katı atıklar, ses ve görsel). Doğal kaynaklar aşırı ve/veya uygun olmayan kullanım nedeniyle tehlikeye atılabilir. Turistik hizmetlerin sağlanması manzara görünümünü değiştirebilir. Turizm geliştikçe, özellikle sahil şeridi, özel manzara ve dağlar gibi birinci sınıf yerlerde araziye olan talep artar (Kreag, 2001: 7-8). Tuna (2007: 22), turizmin sadece doğal çevre üzerinde değil, sosyo-kültürel çevre üzerinde de ve özellikle geleneksel kültürel değerler üzerinde yıkıcı etkilerinin olabileceğini belirtmektedir. Turizmin gelişimi ile birlikte ortaya çıkan olumsuz etkiler, daha geniş kitle pazarının hedeflenmesinden kaynaklanmaktadır. Tuna'ya göre, bu durumda yerel kültür ya turist kültürünü içerir ya da turistlerin getirdiği kültür geleneksel kültürün yapısını dönüştürmek suretiyle yeni kültürel dokuyu oluşturur. Yerli ve yerli olmayan girişimcilerin sosyo-ekonomik temelli olan, fakat kültürel ve etnik görünümler üzerinden ortaya çıkan çatışma, daha kapsamlı toplumsal çatışmalara da yol açabilmektedir (Tuna, 2007: 22-23).

Turizmin toplumsal yapı üzerine hem olumlu ve hem de olumsuz etkileri olduğunu belirten Avcıkurt (2003: 40-49), bu etkilerin turizmin büyüme oranı ve çeşidine, ziyaretçiler ile yerel nüfus oranına, mevsimsel trendlere ve yerel toplumun sosyo-kültürel esnekliğine bağlı olarak değişme göstereceğini vurgulamaktadır. Turizmin toplumsal değişime etkilerini, bireysel davranış, aile ilişkileri, toplu yaşam, ahlaki tutumlar, değer sistemleri, örf ve adetler, geleneksel törenler, toplumsal örgütlenmeler ve sosyo-kültürel başlıklarla ele alan Avcıkurt, toplumun gelişmemiş ya da gelişmekte olan yöre olması ile gelişmiş toplum olması arasında turizmin toplumsal değişime etkisinin az ya da çok farklılıklar gösterebileceğini belirtmektedir. Buna göre turizm, az gelişmiş ve gelişmekte olan toplumları daha fazla düzeyde etkilemektedir. Bu etkinin ortaya çıkardığı sonuç ise, az gelişmiş ve gelişmekte olan toplumların gelişmiş olan toplumların yaşam biçimlerini ve kültürlerini daha çok benimsedikleri şeklindedir. Bu durum şunu göstermektedir ki, ev sahibi ülkenin insanları turizmin yarattığ 1 insan ilişkilerine bağlı olarak daha edilgen bir konumdadır ve ziyaretçilerin kültürel biçimleri yöre insanı 
üzerinde etkili olarak kültürel değişime yol açabilmektedir. Bu kültürel değişimler, dinsel inanç ve davranışlar, ahlaki değerler, yabancılara ait yaşam biçiminin benimsenmesi, dildeki değişimler, geleneksel sanat ve el işlerinde değişimler ve turizmin yerel halkın kültürünün bir parçası haline gelmesi veya turizme bağımlılık olarak ortaya çıkabilmektedir (Avcıkurt, 2003: 48).

Turizm ile birlikte, çekirdek aile tipinde yayılma, birçok çocuğu olan bir aileden az çocuğu olan bir aileye ve geleneksel bir yaşam tarzından modern bir yaşam tarzına geçiş görülmektedir. Yaşam tarzındaki bu değişim sadece aile tipine değil aynı zamanda toplumun diğer boyutlarına da yansır. İnsanların artan harcama alışkanlığı bunlardan sadece biridir (Akis, 2011: 296).

Berber'e göre (2003), turizm alanları değişik kültürlerin bir araya gelmesiyle sosyo-kültürel değişmelere ve değer mübadelesine sahne olur. Değişen sosyo-kültürel ilişkiler ve davranış, kaynak kullanımında yeniden yapılanmaya yol açar. Diğer sosyal ve çevresel güçler, kaynak ilişkilerini değiştirir, bunun sonucunda kaynak kullanımı olumsuz etkilere sebep olur. Turizm ekonomik farklılaşmayı yarattığından çok daha fazla toplumsal farklılaşmayı da yaratmaktadır. Kültürlerin ve değer yargılarının değişmesine neden olmaktadır (Berber, 2003: 220-221).

Oktik ve Öztürk'ün (2007: 205) Muğla'da yaptıkları sosyal yapı araştırmasında, Mazı köyünde görüştükleri sakinlerin, turizmin köylüyü tarım ve halıcılıktan uzaklaştırdığını ifade ettiklerini belirtmişlerdir. Bununla beraber turizm gelirlerinin daha da artacağ yaşayanların turizme bel bağladığının göstergesi niteliğindedir. Bu durum şunu göstermektedir ki; turizmin yörede faaliyet alanı bulması ile birlikte eski geçim araçlarının yavaş yavaş terkedilerek, turizmi yeni iş kapısı olarak görme şeklinde bir değişim yaşanmaktadır.

Kreag (2001), etkileri topluluklara zarar verebileceğinden, turizmin toplumsal ve kültürel sonuçları dikkatle düşünülmesi gerektiğini belirtmektedir. Turistler tarafindan getirilen bazı değerler toplumun davranışlarını ve aile hayatını etkiler. Bireyler ve kolektif toplum, turistleri memnun etmeye veya turistik davranışları benimsemeye çalışabilir. Yerel sakinler ve turistler arasındaki etkileşimler, yeni firsatlar (pozitif) sağlayabilir veya kişiliği yeni kısıtlamalarla bastırarak (negatif) yaratıcı ifadeleri etkileyebilir. Artan turizm, bir toplumu cinsiyetler arasındaki anlayışı geliştirmesi (pozitif) veya yasadışı uyuşturucu kullanımını artırması (negatif) gibi farklı bir ahlaki davranışı benimseme yönünde itebilir. Güvenlik ve sağlı tesisleri ve kişisel eğitim artarken, aynı zamanda suç ve kazalar gibi güvenlik problemleri de artmaktadır (Kreag, 2001: 8-9). Turistler, farklı değerler ve yaşam tarzları olan diğer toplumlardan keyif almaya geldikleri için, büyük miktarlarda para harcayabilir ve evde bile kabul etmeyecekleri şekilde davranabilirler (Dičevska ve Simončeska, 2012:280).

Kültürel etkiler, bir toplumun değerleri, inançları ve kültürel uygulamalarının uzun vadeli, kademeli olarak değişmesine neden olan etkilerdir. Bir ölçüde bu, anlık kültür ve otantik hatıra eşyaları için turistlerin talebi sonucu ortaya çıkar ve aşırı derecede ev sahibi toplumun kültürel açıdan turizme bağımlı hale gelmesine neden olabilir (Sharpely, 1994'den Aktaran Brunt ve Courtney, 1999: 496).

Bahçe (2009), seyahatin nedeni olan kültürün, bizzat ev sahipleri ve ziyaretçilerin etkileşimini gerektirmesi, kaçınılmaz bir şekilde sosyal ve kültürel sonuçlar doğurduğunu belirtmektedir. Bahçe'ye göre, fiziksel, sosyal ve kültürel yapılar üzerindeki yoğun etkileşim genel olarak ev sahipleri aleyhine gelişmektedir. Sürdürülebilirlik ilkeleri dikkate alınmadan izlenen politikalar, doğal kaynakları tükettiği gibi, sosyal ve kültürel dokuyu da olumsuz etkilemektedir (Bahçe, 2009: 5). 
Turizmin topluma getirdiği karanlık bir sosyal ve kültürel yanı da vardır. Yasadışı faaliyetler, reşit olmayanların içki kullanımı, turistik alanların rahat atmosferinde artma eğilimindedir. Yabancılara tanınan ayrıcalıklar, kalabalık turist trafiği, kaçakçıların ve kaçak ürünlerin alıcılarının varlığını artırabilir. Turist sıkışıklığından, şehir merkezlerindeki alışverişlerden kaçınmak için yerel seyahat kalıplarındaki değişiklikler gibi yaşam tarzına yönelik değişiklikler bir toplumun sosyal ve kültürel yapısına zarar verebilir. Oteller, restoranlar ve mağazalar turizmin gelişmesini konut alanlarına itebilir, böylece bir topluluğun fiziki yapısında değişiklikler yaratabilir. Birinci sınıf yerlerde turistik tesislerin geliştirilmesi yerli halkın bu kaynaklardan dışlanmasına veya öyle hissetmesine neden olabilir. Yerel etnik kültür turizmin ihtiyaçlarını karşılamak için değiştikçe, dil ve kültürel uygulamalar değișebilir. Uzun süreli olarak konutlarda konaklayan turistler yerel yaşam normları ile çatışabilirler. Turistlerin "gösterim etkisi" ve turistik tesislerin ilavesi turist davranışlarını benimseyen sakinlerin geleneksel yaşam biçimlerini değiştirebilir. Yerel olmayan arkadaşlarla buluşma ve evlilik potansiyeli aile içinde stres yaratabilir (Kreag, 2001: 10).

Kültür, turistik yerlerin bir parçası olduğu zaman, kültürel niteliklerin aşırı yükseltilmesi ve turistlerin hazlarını tatmin etmek için "yeni" kültürel niteliklerin yaratılması sahte bir kültür yaratabilir. Sakinler, planlama ve kalkınma endişeleri üzerinde dışlanma ve yabancılaşma hissi yaşayabilir. Yabancıların kuruluşları ve yeni gelişmeleri devralmalarından dolayı toplum, geleceği üzerinde kontrol kaybı hissedebilir (Kreag, 2001: 12).

Gürbüz’e (2002: 53-54) göre turizmin, dostluk ve arkadaşlığın gelişmesi yoluyla dünya barışına katk1, halkın eğitim ve kültür düzeylerinde artış, ekonomik katkıları korumak ve güçlendirmek amacıyla kültürel değerlere sahip çıkılması, kentsel yaşam olanaklarına daha fazla sahip olma gibi sosyal çevre üzerine olumlu etkileri vardır. Turizmin sosyal çevre üzerine olumlu etkileri yanında olumsuz etkileri de vardır. Bunlar; değer ve inanç yapısının değişmesi, giyim ve yaşam biçimlerinde değişiklikler, sanatsal değerlerin yok olması ve yerini yapay çalışmaların alması, mimari estetiklerdeki tahribat ve betonlaşma, insanlar arası ilişkilerde parasallaşma, iş dişı boş zamanların değerlendirilmesinde geleneksel aktivitelerin yerini bar, gece kulübü v.b. yerlerin alması, turistlere özenme ve onlar gibi davranma, kültürel çatışma durumlarının ortaya çıkmasıdır (Gürbüz, 2002: 54). Öte yandan Demirbulat (2012), turizmin yöre halkının inanç ve ahlaki değerlerinde olumsuz bir değişime neden olmadığını ve hayat tarzlarının, yeme-içme ve kılık kıyafet alışkanlıklarında turizm kaynaklı bir değişim yaşanmadığını ileri sürmektedir (Demirbulat, 2012: 71). Civelek (2010:334) ise ziyaretçilerin kendi yaşam tarzlarını gittikleri yörede sürdürmelerinin yöre insanının yaşam tarzı ve tutumları üzerinde etkili olduğunu belirtmektedir.

Yabancı turistler ve getirdikleri kültür ile yerel kültür karşılaşmasında yabancı kültürün daha baskın bir karakter sergilediği söylenebilir. Bunun belli başlı nedenleri arasında ilk olarak bu etkileşimin bir taraf için sürekli haldeyken, diğer taraf için geçici bir halde olması sayılabilir. Yerel halk sürekli olarak bu yabancı kültüre ait yaşam biçimlerine tanık olurken, ziyaretçiler o yöreye ilişkin kültürü kısa bir süreliğine deneyimlemektedirler. İkinci olarak ise küresel ölçekte yaşanan bir "batıllılaşma" kültürünün etkisi sayılabilir. Bu etki turizmden bağımsız olarak baskın batı kültürünün dünya çapında yaygınlaşmasının bir sonucu olarak ortaya çıkarken, öte yandan turizm vasıtasıyla batıya ait bu kültürün ete kemiğe bürünmüş şekilde yöre insanı ile etkileşime geçmesinden dolayı bu etkinin gücü daha fazla yaşanabilmektedir. Urry (1988: 35), son yarım yüzyılda yaşanan kültürel değişimin postmodernizim ile ilişkili kültürel dönüşümden ayrılamayacağını belirtmektedir. Lane (1988) artan turizm hareketleri sonucunda toplumdaki değişimin "batılılaşma" sürecinin bir parçası haline geldiğini belirtmektedir. Kültüre özgü bazı ritüeller ve danslar, gerçek durumlarından çıkarılmak suretiyle ve gerçek mekânlarından ziyade, turistlerin topluca bulunduğu otel ya da eğlence yerlerinde gösterime tabi tutulmaktadır (Lane, 1988: 66-69). 
Toplumsal ve kültürel değişimin bir aracı olarak turizm, bölgelerin hem kültürel zenginleştirilmesi hem de gençleşmesi için bir kuvvet olarak tanımlanmaktadır. Kültürel turizmin önemli bir parçası olan miras turizmi, belirli bir alanın veya bölgenin tarihi, kültürel ve doğal kaynaklarını otantik olarak temsil eden yerleri ve faaliyetleri deneyimlemeye dayalıdır (Forga ve Valiente, 2017: 265-267). Doğal ve kültürel miras tarih öncesi ve tarihi devirlere ait bilim, kültür, din ve güzel sanatlarla ilgili tüm maddi ve maddi olmayan varlıklar olarak tanımlanmaktadır. Geçmişten devralınan miras kültürel turizmi doğurur ve geliş̧irir. Kültür ve tabiat varlıklarından, tarihi, arkeolojik, doğal sit alanları, anıt, ören yeri, tümülüs, külliye, cami, kilise yasalarla koruma altına alınmış olan maddi kültür varlıklarını oluşturur (Doğaner, 2003: 2'den aktaran Emekli, 2006: 56). Ayrıca soyut ya da maddi olmayan kültür varlıkları olarak gelenek ve görenekler, folklorik değerler, dini inanış ve değerler, müzik, dans ve yeme-içme alışkanlıkları kültür turizmini tamamlayan unsurlar olarak dikkat çekmektedir (Emekli, 2006:56).

Mathur (2011), turizmin sosyal etkileri bakımından daha iyimser bir görüş benimsemektedir. Ona göre turizm; kaybolan geleneklerin yeniden canlanması sağlar; küresel boyutta insana sayg1 hassasiyetini geliştirir; kültürel kabul, etkileşim ve farkındalığı artırır; sanat ve kültürün korunmasını teşvik eder ve ziyaretçilere saygıyı ve onlarla bağlantı kurulmasını güçlendirir. Turizm, insan etkileşimlerinin endüstrisidir ve toplumda inanç ve güven oluşturmaktadır. Turizm nedeniyle küresel düzeyde meydana gelen değişiklikler tüm kültürlerden insanlara farklı din ve değerleri birleştirmektedir. Toplum temelli turizm yaklaşımı halka, yerel değerlerin ve kaynakların korunmasına katılmayı, sürdürülebilirliği ve turizmin kalitesini yönetmek suretiyle topluma faydalı olmasını öğretmektedir (Mathur, 2011: 286-287). Turizmin yerel halk üzerindeki etkisinin değerlendirilmesi, sadece doğrudan maliyetlere, yaratılan kar ve iş gibi faydalara değil, olumlu, olumsuz ve dolaylı çeşitli etkilere bağlıdır. Turizmin etkileri aşağıdakiler açısından değerlendirilebilir (Ashley, 2000: 17):

- Hanehalkı varlıkları üzerindeki etkiler

- Hane halkının diğer faaliyetleri ve stratejileri üzerine etkiler

- Çeşitli hane halkı hedeflerine katkıda bulunulması

- Dış politika ortamına ve insanların dış güçleri etkileme kapasitesine etkisi.

Turizmin zorlamasıyla güçlenen sosyal değişim, olumlu olduğu kadar olumsuz da olabilir. Turizm, yerel insanlar için yeni bir kırsal etkinliktir ve doğal olarak riskli olarak algılanmaktadır. Dolayısıyla, ek bir etkinlik, yerine geçmek değil, mevcut geçim faaliyetleriyle birleşmek için bir şans olarak görülmelidir. Turizmin mevcut faaliyetlerle tamamlayıcı ya da onlarla çatışmacı etkileri topluluk ve hane içi tartışmalarda kilit bir tema olarak ortaya çıkmıştır. Yerel kültüre odaklanan bazı turizm faaliyetleri, gelenekleri güçlendirmeye yardımcı olabilir; bununla birlikte, kültürel değerlerin önemini azaltma riski de vardır (Ashley, 2000: 17-22). Enemuo ve Oduntan'a (2012) göre turizm, ev sahibi topluluklardaki sosyal ve kültürel değişimlere katkıda bulunabilir. Buna, yaşam standardında ve sosyal yaşamlarındaki değişiklikler de dâhildir. Olumsuz sosyal etkilerin ölçülmesi zordur ve büyük ölçüde dolaylı etkiler altında gerçekleşir. $\mathrm{Bu}$ etkiler, olumsuz konulara yönelik önlemler ve politikalar geliştirilmediği takdirde, turizm destinasyonlarının hayatta kalmasını tehdit edebilir (Enemuo ve Oduntan, 2012: 35).

Turizm paydaşları özellikle, turizmin sosyal etkileri konusunda farkındalık programları oluşturmalıdır. $\mathrm{Bu}$, toplulukların geleneksel değerlerini korumalarına ve kültürel miraslarının aşınmasını önlemelerine yardımcı olacaktır. Hedefin sürdürülebilirliğini ve ev sahibi toplulukların sosyal yaşamlarını güvence altına alan politikalar ve uygulamalar, sanayinin olgunlaşmasında olumsuz sosyal etkileri önlemek için turizm gelişiminin ilk aşamasında geliştirilmelidir. Sürdürülebilir turizm gelişimi için bir ön koşul olan ev sahibi toplum katılımı, ev sahibi topluluğa toplumun kaynakları üzerinde bir mülkiyet ve kontrol duygusu kazandırmak için turizm geliştirme süreçlerinde teşvik edilmeli ve kolaylaştırılmalıdır (Enemuo ve Oduntan, 2012: 35). 
Kumar ve Kumar'a (2014) göre, değișim doğanın bir kuralıdır. Bir toplumun ya da kültürün başka bir toplum ya da kültürle temasa geçmesi doğal olarak gerçekleşir. Kültür, turizm olsun ya da olmasın dinamiktir. Turizm nedeniyle bir kültürün varlığı tehlike altında değildir, gerçek tehlike, toplulukların turizmin gelişiminin sınırlarını yönetme gücünün aşınmasında yatmaktadır. Farklı turizm gelişmelerinde toplum katılımının uygun bir payı varsa ve insanlar kontrolü elinde tutuyorsa, orijinal sosyal gelenek ve normlar daha az etkilenecek ve kültür turizmi üzerindeki olumsuz etkiler azaltılacaktır. Öte yandan yönetimde toplum katılımı, politika oluşturma ve karar verme yetkisi bulunmuyorsa, kontrol tamamen yerel halkın elinden çıkacak ve turizmin kendisini öldürecektir ( Kumar ve Kumar, 2014: 43).

Doğal çevrenin farklılı̆̆ kültüre yansımakta, kültür hem doğal çevreyi hem de toplumu etkilemektedir. Kültür bir çeşit çevreye uyumdur. Kültür bir halkın yalnızca hayat tarzları mozaiği değil aynı zamanda hâkim değer ve inançları da kapsayan bir kavramdır. Emekli'ye (2006) göre, farklı mekânlarda farklı kültürlerin buluşması turizmi geliştiren faktörlerin başında gelmektedir. Geleneksel mimari, dinsel motifler, yerleşme, arazi kullanımı, kılık kıyafet tarzı, el sanatları, yemekler, müzik, güzel sanatlarla ilgili eserler hem kültürel coğrafi görünümün bir parçası hem de coğrafya-kültür ve turizmin odak noktasidır (Emekli, 2006: 53).

Kültürel turizminin mevsimsel olmama özelliği, turizmin zamana-mekâna yayılması için etkili bir araçtır. Maddi ve maddi olmayan kültürel değerler turizm yoluyla ekonomik bir değer kazanır. Kültür turizmi iyi yönetildiği takdirde kültürel varlıkların korunmasına imkân sağlarken, iyi yönetilmediği takdirde ise bu değerlerin zamanla aşınmasına, bozulmasına ve hatta yok olmasına yol açabilir (Emekli, 2006: 55).

Sürdürülebilir olarak kültürel varlıkların turizme kazandırılarak ekonomik bir değere dönüştürülmesi arz-talep arasındaki dengenin iyi kurulması ile mümkündür. Yörenin taşıma kapasitesinin üzerinde bir yoğunluk olması, sosyal ve kültürel varlıklar için bir tehdit niteliğindedir. Özdemir ve Kervankıran'a (2011: 22) göre, plansız bir gelişmenin sonucu olarak taşıma kapasitesinin üzerinde bir turizm yoğunluğu, çevresel ve toplumsal sorunlara yol açabilir. Çevrenin geri dönülemez bir şekilde tahribatı, sosyo-kültürel çatışmalar ve toplumsal değerlerin kaybolması (Özdemir ve Kervankıran, 2011: 22) riski turizmin ekonomik faydaları yanında sosyal ve kültürel maliyetlerinin de olabileceği gerçeğini göz önüne serer.

Muğla ili özelinde, turizmin yerel halkın sosyal ve kültürel yaşamına etkisi ile ilgili olarak Özel (2014), Muğla'nın önemli turizm merkezlerinden biri olan Marmaris'te yaptığı çalışmada, toplumun geleneksel yapı içerisinde önemli bir özellik olan toplumsal dayanışmanın zayıfladığı, aile birliğine olumsuz yansımaları olduğu, yabancılarla yapılan evliliklerin kültür çatışmasına yol açtı̆̆ 1 ve kadınların iş yaşamına katılmalarının turizm sayesinde arttı̆̆ 1 sonucuna varmıştır. Toplumsal dayanışmadaki zayıflama, aile birliğinin bozulması gibi geleneksel toplum yapısında görülen bu özelliklerin doğrudan sorumlusunun turizm olduğu fikri tartışmalıdır. Giddens'ın (2008: 75) belirttiği gibi, batıda başlayan ve tüm dünyayı etkisine alan sanayi devriminin bir sonucu olarak ortaya çıkmış olan kapitalizm, batının sahip olduğu ekonomik güç, siyasal birlik ve askeri üstünlükle birlikte egemen bir güç olarak batıya ait yaşam biçiminin karşı konulamaz bir şekilde yayılmasına yol açmıştır. Elbette turizm, ekonomik bir faaliyet olarak kapitalizmin küresel boyutta önemli bir faaliyet alanıdır ve bu yolla batıya ait yaşam biçimi, turizm merkezlerindeki yerel halkın geleneksel yaşam biçimine etki eder.

Yıldız ve Çalışkan, turizm faaliyetlerinin yoğun olmadığı ancak turizm merkezlerine yakın olan Muğla'nın merkez ilçesi Menteşe halkı üzerine yaptıkları çalışmada, buradaki halkın turizmin sadece ekonomik etkilerini değil, sosyal ve kültürel etkilerini de aynı derecede önemsediği sonucuna varmışlardır. Bunun temel nedeni ise halkın gelirinin turizme dayanmaması olarak açıklamışlardır (Yıldız ve Çalışkan: 237). Gerçekten de, bir faaliyetin ekonomik olarak yaratacağı etki, diğer etkilerin göz ardı edilmesine ya da yeterince önemsenmemesine yol açabilmektedir. 
Biçici'nin (2013) Muğla'nın Datça ilçesinde yaptığ çalışmada, yerel halkın turizmin sosyal maliyetine ilişkin kaygı taşımadıkları sonucuna ulaşmıştır. Oysa uzun dönemde, sürdürülebilir bir turizm gelişimi için yerel halkın sosyal ve kültürel yapısının korunmasının önemine dikkat çekmiştir (Biçici, 2013:31). Halkın genel olarak turizmin ekonomik etkilerini birincil olumlu etki olarak gördüklerinden, sosyal ve kültürel etkilerinin ikinci plana itildiği anlaşılmaktadır.

\section{MUĞLA'DA TURIZMIN EKONOMIK VE DEMOGRAFIKK DEĞİŞIME ETKİSI}

Muğla, Ege Bölgesinin güneyinde, 1124 km sahil uzunluğuna sahip, Dünyaca ünlü körfez ve koyları olan, yüzölçümünün \% 67'si ormanlık, zengin bir kültürel mirasa sahip ve turizm arz çekicilikleri bakımından Türkiye'nin gözde illerinden biridir. Antalya ve İstanbul'dan sonra en çok turist çeken üçüncü ildir. Yatak sayısı bakımından ise Antalya'dan sonra en çok yatak sayısına sahip ikinci il konumundadır. Turizm sektöründeki gelişmişliğin yanı sıra tarım, hayvancılık ve sanayii sektöründe de ülke ekonomisine önemli katkılar sağlamaktadır (Bahar, 2008: 68).

Araștırmada Muğla ilinin turistik ve turistik olmayan ilçeleri karşılaștırmalı bir șekilde seçilmiştir. Bu turizm merkezlerinin 1965 'lerden bu yana nüfusunun nasıl bir değişim gösterdiği tablo ve grafikler yardımıyla incelenmiştir. Araştırmada ikincil veri kaynakları kullanılmış ve turizm gelirinin nüfus üzerine etkileri regresyon analizi ile tespit edilmiştir. Muğla ili ilçelerinin ekonomik yatırım ve ürettikleri istihdam değerleri tablo ve grafik yardımıyla analiz edilmiștir. SEGE'nin (2011) ekonomik ve sosyal gelişmişlik endeksi verileri incelenmiş ve Muğla ili ilgili kısmı analiz edilerek yorumlanmıştır. İlin kültürel ve ekonomik değişim ile ilgili araştırma ve istatistiki bilgilerin yetersizliği nedeniyle konu teorik çerçevede ele alınmış ve sonuç kısmında değerlendirilmiştir.

Muğla ilinin 1965'lerden günümüze nüfus yoğunluğundaki değişim aşağıda tablo 1'de ve grafik 1'de gösterilmiştir. Beş yıllık dönemler halinde nüfus bilgileri tabloda yer alırken, 1995 ve 2005 yıllarına ait nüfus verileri bulunamadığından bu yıllar tabloda gösterilememiştir.

\section{Tablo 1: Muğla İli ve İlçeleri Nüfus Bilgileri}

\begin{tabular}{|l|l|l|l|l|l|l|l|l|l|l|l|l|}
\hline Y11 & Bodrum & Fethiye & Marmaris & Yatağan & Milas & Ula & Köyceğiz & Datça & Ortaca & Dala-man & $\begin{array}{c}\text { Kavak- } \\
\text { lidere }\end{array}$ & $\begin{array}{c}\text { Muğla } \\
\text { Genel }\end{array}$ \\
\hline 1965 & 25.811 & 75.202 & 12.780 & 36.267 & 68.037 & 15.185 & 45.062 & 6.094 & - & - & - & 368.776 \\
\hline 1970 & 27.383 & 81.640 & 13.518 & 40.297 & 73.334 & 15.737 & 56.380 & 6.312 & - & - & - & 400.796 \\
\hline 1975 & 29.490 & 93.960 & 15.477 & 41.198 & 78.685 & 16.723 & 62.253 & 7.532 & - & - & - & 438.145 \\
\hline 1980 & 32.517 & 101.879 & 19.249 & 46.113 & 81.643 & 17.550 & 71.194 & 8.276 & - & - & - & 486.290 \\
\hline 1985 & 37.966 & 114.384 & 24.742 & 51.016 & 91.387 & 18.152 & 49.874 & 10.741 & - & 26.408 & - & 562.809 \\
\hline 1990 & 56.821 & 127.620 & 41.840 & 42.376 & 98.710 & 19.978 & 25.836 & 13.914 & 35.670 & 28.148 & 12.548 & 715.328 \\
\hline 2000 & 97.826 & 154.209 & 79.302 & 46.252 & 112.808 & 21.944 & 29.196 & 14.836 & 39.648 & 31.318 & 11.153 & 766.156 \\
\hline 2007 & 105.474 & 173.426 & 73.461 & 46.275 & 120.508 & 23.455 & 32.395 & 16.008 & 40.649 & 32.367 & 11.169 & 791.424 \\
\hline 2010 & 124.820 & 188.259 & 77.390 & 45.830 & 125.727 & 23.749 & 32.817 & 16.475 & 42.364 & 33.980 & 11.132 & 817.503 \\
\hline 2015 & 155.815 & 147.703 & 89.630 & 44.363 & 132.437 & 23.618 & 34.363 & 20.029 & 45.875 & 37.406 & 10.759 & 908.877 \\
\hline
\end{tabular}

Kaynak: YerelNet- Yerel Yönetimler Portal1. www.yerelnet.org.tr ve Nufusu.com

Tablo 1'de, Muğla ili ve ilçelerine ait nüfus bilgilerinin 1965-2015 arası değişimleri gösterilmektedir. Bodrum'un nüfusu yaklaşık altı kat, Marmaris'in yedi kat, Datça'nın üç kat ve Fethiye'nin ise iki kat artığı gözlemlenmektedir. Ayrıca Milas'ın nüfusu da turizm merkezlerine 
yakınlığı ve tarım, su ürünleri ve madencilik sektörlerindeki potansiyeli nedeniyle yaklaşık iki kat artmıştır. Bunun yanında Yatağan, Ula, Ortaca ve Dalaman'daki nüfus artışının sınırlı olduğu görülmektedir. Köyceğiz ve Kavaklıdere'nin nüfuslarında ise az da olsa düşüş olmuştur. Muğla İlinin genel olarak nüfusu ise turizm merkezlerinin etkisiyle yaklaşık 2.5 kat arttığ 1 görülmektedir. Bu durum Türkiye'nin genel nüfus artış oranı (2.6 kat) ile hemen hemen aynıdır.

\section{Grafik 1: Muğla İli İlçelerinin Nüfuslarındaki Değişim}

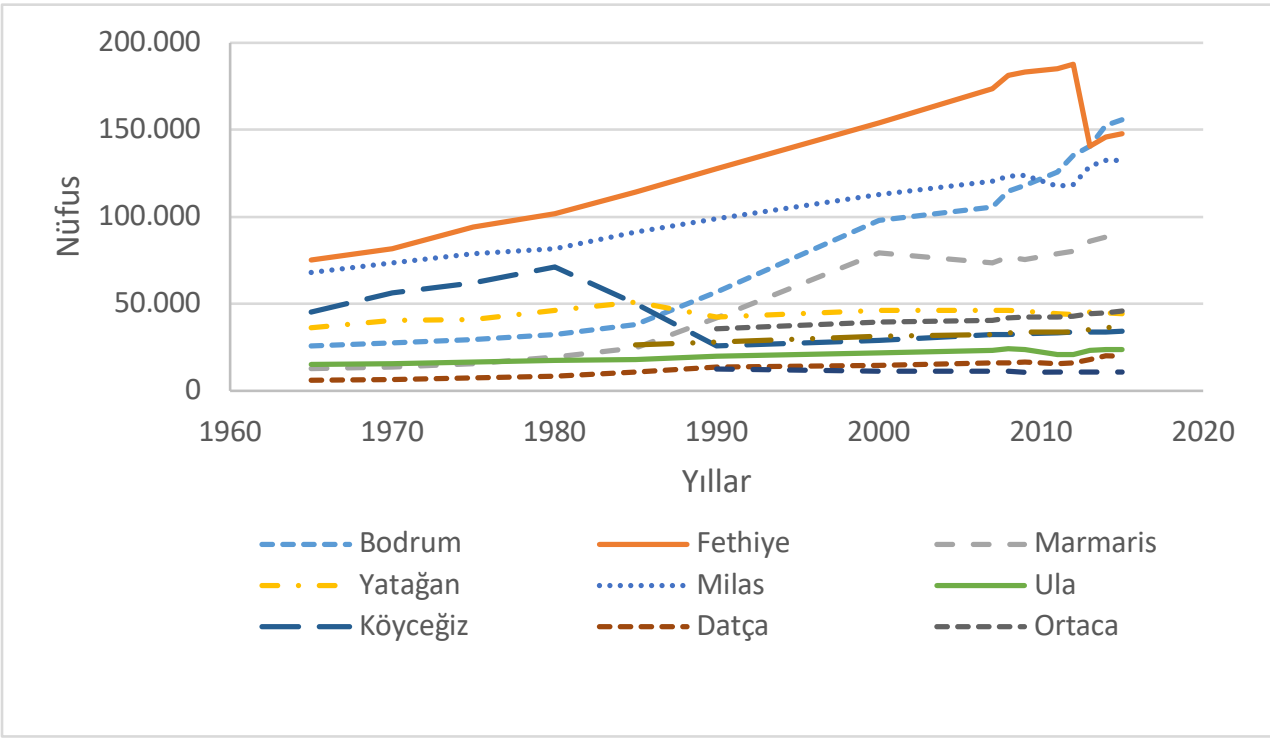

Grafik 1'de, Turizm merkezleri olan Bodrum, Marmaris ve Fethiye'nin nüfuslarındaki değişim özellikle göze çarpmaktadır. Her üç merkezin de nüfuslarının önemli oranda arttığı gözlemlenirken, Fethiye'nin 2013 yılı itibariyle nüfusundaki azalmanın Muğla'nın yeni kurulan ilçesi Seydikemer'in Fethiye'den aldığı nüfus etkisinden olduğu söylenebilir. Ayrıca Milas'ın nüfusunun da önemli ölçüde artış gösterdiği görülmektedir. Diğer ilçelerin ise nüfuslarının yıllar içinde önemli ölçüde değişim göstermediği görülmektedir.

Tablo 2: Yıllar İtibariyle Turizm Geliri ve Muğla-Bodrum-Fethiye-Marmaris-Yatağan-Ula Nüfusları Karșılaștırması

\begin{tabular}{|c|c|c|c|c|c|c|c|}
\hline Y1llar & $\begin{array}{c}\text { Turizm } \\
\text { Geliri } \\
\left(\begin{array}{c}\text { Milyon } \\
\$)\end{array}\right.\end{array}$ & $\begin{array}{c}\text { Muğla } \\
\text { İli } \\
\text { Nüfusu }\end{array}$ & $\begin{array}{c}\text { Bodrum } \\
\text { İlçesi } \\
\text { Nüfusu }\end{array}$ & $\begin{array}{c}\text { Fethiye } \\
\text { İçesi } \\
\text { Nüfusu }\end{array}$ & $\begin{array}{c}\text { Marmaris } \\
\text { İlçesi } \\
\text { Nüfusu }\end{array}$ & $\begin{array}{c}\text { Yatağan } \\
\text { Illçesi } \\
\text { Nüfusu }\end{array}$ & $\begin{array}{c}\text { Ula } \\
\text { İlçesi } \\
\text { Nüfusu }\end{array}$ \\
\hline 1965 & 11,6 & 334.973 & 25.811 & 75.202 & 12.780 & 36.267 & 15.185 \\
\hline 1970 & 51,5 & 368.776 & 27.383 & 81.640 & 13.518 & 40.297 & 15.737 \\
\hline 1975 & 200 & 400.796 & 29.490 & 93.960 & 15.477 & 41.198 & 16.723 \\
\hline 1980 & 326 & 438.145 & 32.517 & 101.879 & 19.249 & 46.113 & 17.550 \\
\hline 1985 & 1.094 & 486.290 & 37.966 & 114.384 & 24.742 & 51.016 & 18.152 \\
\hline 1990 & 3.225 & 562.809 & 56.821 & 127.620 & 41.840 & 42.376 & 19.978 \\
\hline
\end{tabular}




\begin{tabular}{|c|c|c|c|c|c|c|c|}
\hline 2000 & 7.636 & 715.328 & 97.826 & 154.209 & 79.302 & 46.252 & 21.944 \\
\hline 2010 & 24.930 & 817.503 & 124.820 & 188.219 & 77.390 & 45.830 & 23.749 \\
\hline 2015 & 31.646 & 908.877 & 155.815 & 147.703 & 89.630 & 44.363 & 23.618 \\
\hline 2017 & 26.283 & 938.751 & 164.158 & 153.963 & 91.871 & 44.515 & 24.419 \\
\hline
\end{tabular}

Kaynak: TUIKK ve YerelNet- Yerel Yönetimler Portal1. www.yerelnet.org.tr

Turizm gelirine bağlı olarak genel olarak Muğla ve Bodrum, Marmaris, Fethiye gibi turizm yöreleri ile bir turizm yöresi olmayan Yatağan ve kısmen turizm yöresi sayılabilecek Ula ilçesinin nüfuslarındaki değişim regresyon analizleri ile incelenmiştir.

Tablo 3: Turizm Gelirinin Muğla Nüfusuna Etkisi

\begin{tabular}{|ll|l|l|l|}
\hline Bağıml Değişken & & $\beta$ & $\mathrm{t}$ & $\mathrm{p}$ \\
\hline Muğla & &, 941 & 7,889 &, 000 \\
\hline $\mathrm{R}=, 941 \quad \mathrm{R}^{2}=, 886$ & $\mathrm{p}<, 000$ & $\mathrm{~F}=62,233$ \\
\hline
\end{tabular}

Tablo 4: Turizm Gelirinin Bodrum Nüfusuna Etkisi

\begin{tabular}{|ll|l|l|l|}
\hline Bağımlı Değişken & $\beta$ & $\mathrm{t}$ & $\mathrm{p}$ \\
\hline Bodrum & &, 964 & 10,321 &, 000 \\
\hline $\mathrm{R}=, 964 \quad \mathrm{R}^{2}=, 930$ & $\mathrm{p}<, 000$ & $\mathrm{~F}=106,516$ & \\
\hline
\end{tabular}

Tablo 5: Turizm Gelirinin Fethiye Nüfusuna Etkisi

\begin{tabular}{|lc|c|c|c|}
\hline Bağımlı Değişken & $\beta$ & $\mathrm{t}$ & $\mathrm{p}$ \\
\hline Fethiye & &, 795 & 3,705 &, 006 \\
\hline $\mathrm{R}=, 795 \quad \mathrm{R}^{2}=, 632$ & $\mathrm{p}<, 000$ & $\mathrm{~F}=13,730$ & \\
\hline
\end{tabular}

Tablo 6: Turizm Gelirinin Marmaris Nüfusuna Etkisi

\begin{tabular}{|ll|l|l|l|}
\hline Bağımlı Değişken & & $\beta$ & $\mathrm{t}$ & $\mathrm{p}$ \\
\hline Marmaris & &, 899 & 5,800 &, 000 \\
\hline $\mathrm{R}=, 899 \quad \mathrm{R}^{2}=, 808$ & $\mathrm{p}<, 000$ & $\mathrm{~F}=33,640$ & \\
\hline
\end{tabular}

Tablo 7: Turizm Gelirinin Yatağan Nüfusuna Etkisi

\begin{tabular}{|l|l|l|l|}
\hline Bağımlı Değişken & $\beta$ & $\mathrm{t}$ & $\mathrm{p}$ \\
\hline
\end{tabular}




\begin{tabular}{|lll|l|l|l|}
\hline Yatağan & &, 231 & 670 &, 522 \\
\hline $\mathrm{R}=, 231 \quad \mathrm{R}^{2}=, 053$ & $\mathrm{p}<, 000 \quad \mathrm{~F}=, 449$ & \\
\hline
\end{tabular}

Tablo 8: Turizm Gelirinin Ula Nüfusuna Etkisi

\begin{tabular}{|ll|l|l|l|}
\hline Bağımlı Değişken & & $\beta$ & $\mathrm{t}$ & $\mathrm{p}$ \\
\hline Ula & &, 898 & 5,762 &, 000 \\
\hline $\mathrm{R}=, 898 \quad \mathrm{R}^{2}=, 0806$ & $\mathrm{p}<, 000$ & $\mathrm{~F}=, 33,199$ \\
\hline
\end{tabular}

Tablo 3, 4, 5, 6, 7 ve 8'de, turizm gelirinin Muğla ili ve ilçelerinden turizm yöresi olan Bodrum, Fethiye ve Marmaris ile turizm yöresi olmayan Yatağan ve kısmen turizm yöresi olan Ula nüfusuna olan etkisi regresyon analizi yardımıyla gösterilmiştir. Buna göre, genel olarak Muğla ili ve Bodrum, Fethiye, Marmaris ve Ula ilçelerinin nüfuslarına turizm gelirinin güçlü pozitif etkisi olduğu görülmektedir. Turizm gelirinin Yatağan ilçesinin nüfusuna ise anlamlı bir etkisinin olmadığı anlaşılmaktadır.

Muğla ilinin 2010-2015 yılları itibariyle ilçelerinde yapılan yatırımların sayısı, yatırımların ekonomik değerleri ve yarattıkları istihdam bakımından durumu tablo 9'da ve grafik 2'de gösterilmiştir.

Tablo 9: Muğla İlçelerinde Yatırımların Dağılımı (2010-2015)

\begin{tabular}{|l|c|c|c|}
\hline İlçeler & $\begin{array}{l}\text { Belge } \\
\text { Say1s1 }\end{array}$ & $\begin{array}{l}\text { Yatırım Tutar1 } \\
\text { (Milyon TL) }\end{array}$ & İstihdam \\
\hline Bodrum & 80 & 867 & 2753 \\
\hline Dalaman & 10 & 90 & 467 \\
\hline Datça & 7 & 75 & 123 \\
\hline Fethiye & 79 & 587 & 2114 \\
\hline Kavaklıdere & 11 & 40 & 154 \\
\hline Köyceğiz & 7 & 37 & 73 \\
\hline Marmaris & 53 & 504 & 2311 \\
\hline Menteşe & 47 & 825 & 892 \\
\hline Milas & 57 & 643 & 1946 \\
\hline Ortaca & 9 & 49 & 190 \\
\hline Ula & 15 & 95 & 291 \\
\hline Yatağan & 36 & 138 & 353 \\
\hline Genel Toplam & 411 & 3950 & 11667 \\
\hline
\end{tabular}

Kaynak: Yatırım Teşvik Belgeleri İstatistikleri, T.C. Ekonomi Bakanlığı-GEKA 2017 


\section{Grafik 2: Muğla İlçelerinde Yatırımların Dağılımı (2010-2015)}

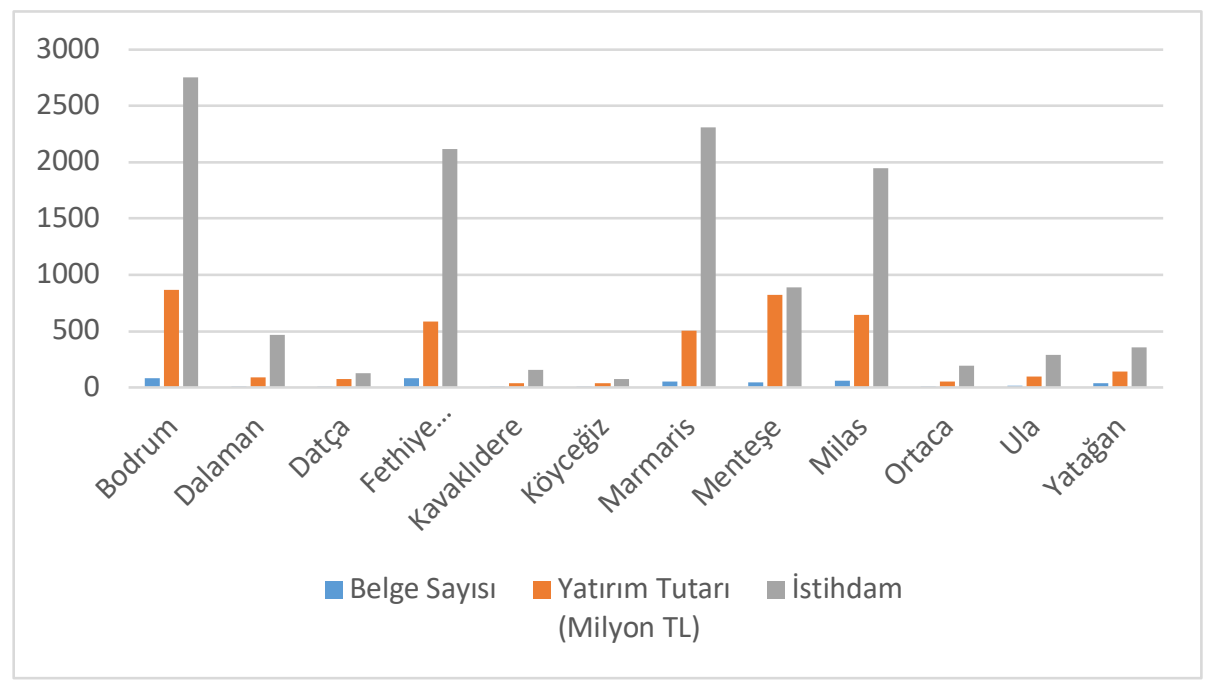

Tablo 9 ve Grafik 2'de görüldüğü üzere, Muğla ilinin ilçeleri arasında en fazla istihdam yaratan ilçeler sırasıyla Bodrum, Marmaris, Fethiye (Seydikemer ile birlikte) ve Milas olarak göze çarpmaktadır. Yatırımların buralarda yoğunlaşmasının temel sebebi turizm faaliyetleri olduğu rahatlıkla söylenebilir. Milas ise diğer merkezler kadar bir turizm yöresi olmamasına rağmen, hem kıyı kesimlerinde yapılan turizm yatırımları ve hem de üretim balıkçılığı, madencilik ve tarım gibi alanlardaki yatırımlar nedeniyle istihdam yaratan önemli bir ilçe konumundadır.

SEGE (Sosyo-Ekonomik Gelişmişlik Endeksi)'nin 2011 yılı araştırmasına göre, Muğla ve Antalya illeri birinci kademedeki ilk on il arasındadır. Uluslararası çekim merkezleri olan bu iller, gelişmiş turizm imkânları sayesinde ilk on il arasında yerlerini almıştır. Turizm yatırım-işletme ve belediye belgeli yatak sayısı itibarıyla Antalya ve Muğla illeri 81 il içerisinde ilk iki sırada yer almaktadır. Türkiye'nin turizm sektöründe sahip olduğu her 100 yataktan 34,6's1 Antalya'da, 15'i ise Muğla'da bulunmaktadır.

\section{Şekil 1: Birinci Kademe Geliş̧̧iş İller}

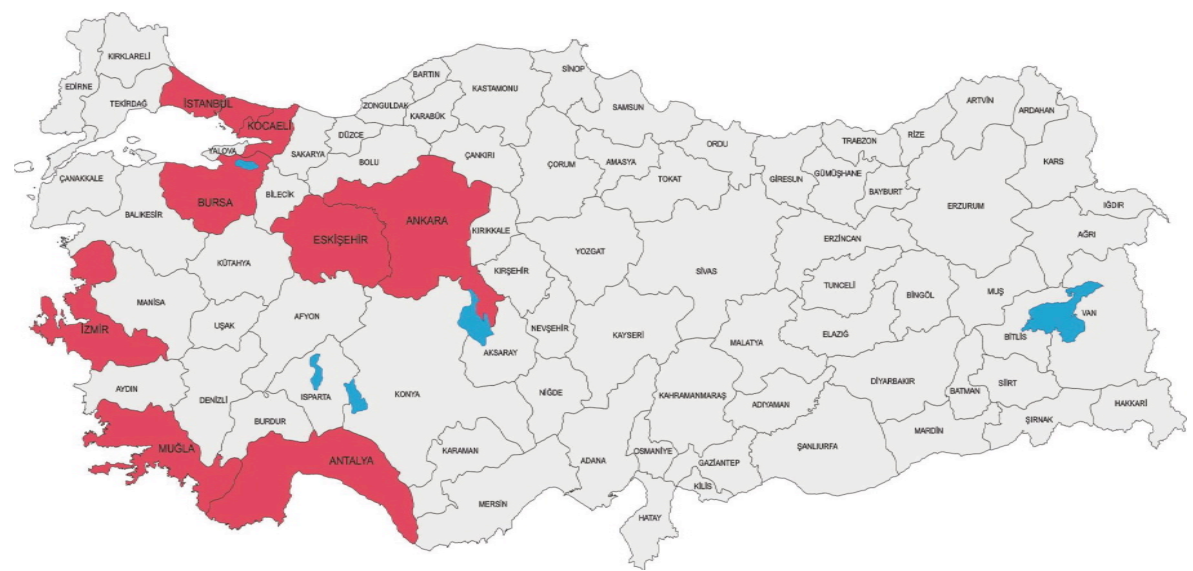

Kaynak: SEGE-2011 (2013), İllerin ve Bölgelerin Sosyo-Ekonomik Gelişmişlik Sıralaması Araştırması, T.C. Kalkınma Bakanlığı, s. 55

SEGE-2011 tarafından yapılan araştırmanın istatistiki bölge birimleri sınıflamasına göre Muğla ili, Aydın ve Denizli ile birlikte 7. sırayı paylaşmaktadır. Burada da özellikle turizmin bölgenin sosyoekonomik gelişiminde ana faktör olduğu söylenebilir. SEGE-2011'in yaptığı bu sosyo-ekonomik gelişmişlik sıralaması çalışmasında 58 adet gösterge kullanılmış olup, sosyal göstergeler başlığı altında 
demografi, eğitim, sağlık, istihdam, altyapı ve diğer refah göstergelerine yer verilmiştir. Ekonomik göstergeler altında ise imalat sanayii, inşaat, tarım ve mali göstergeler bulunmaktadır.

\section{SONUÇ}

Turizmin bir yörede meydana getirdiği en başta ortaya çıkan etki, onun ekonomik bir girdi sağlaması nedeniyle yarattığı toplumsal kabuldür. Bu etki o yörede yaşayanlar başta olmak üzere birçok hanenin gelirini artırıcı bir etki sağlamaktadır. Bazen bu gelir etkisi aslen yapılan işlerin terkedilip örneğin, tarım ve hayvanc1lık gibi- turizmi ana gelir merkezi olarak görmeye kadar iten sonuçlar doğurmaktadır. Turizmin olmadığı ya da düşük seviyede olduğu zamanlarda toplumdaki iş bölümü ve üretim ilişkileri daha çok kendi toprağı üzerinde hane halkının çalışması üzerine kurulu ilişkilerden oluşmaktaydı. Turizmin gelişmesi ile birlikte yeni iş olanaklarının ortaya çıkması bu insanları yeni açılan işletmelerde çalışan işçi konumuna getirmiştir. Turizmin ekonomik bakımdan toplumda meydana getirdiği etki, üretim ilişkilerindeki değişimdir. Aykaç (2009: 105), farklı bir soyutlama düzeyinde turizmdeki emek dönüşümünün sosyal ve ekonomik iz düşümlerinin önceki dönemle paralellik gösterdiğini ifade etmektedir. Erken sanayileşme döneminde tarımdan sanayiye doğru bir emek dönüşümü yaşanmışken, turizm sektöründe de benzer bir şekilde tarımdan turizme doğru bir emek dönüşümü gerçekleşmiştir.

Kadınların ve gençlerin, turizmin sağladığı istihdam nedeniyle daha çok iş hayatına katılımları artabilmektedir. Böylece hane içi toplumsal rollerin de değiştiği bir durum ortaya çikmaktadır. Özellikle genç ve orta yaştaki kadınlar bir yandan aile içi sorumluluklarını sürdürürken, diğer yandan ekonomik olarak aile bütçesine katkı sağlaması açısından da önemli bir rol üstlenmiş durumdadırlar. Bu durum zaman zaman aile içi çatışmaların ortaya çıkmasına neden olabilmektedir. Eşlerden ikisinin birden turizm işletmelerinde çalışması durumunda, turizmin sosyal olmayan çalışma saatleri nedeniyle birbirleriyle ve çocukları ile geçirdikleri zaman azalmaktadır. Kısacası turizmin aile içi ilişkileri etkileyen bir yönü de vardır. Tuna'nın (2007) araştırmasında ortaya koyduğu gibi, katılımcıların büyük çoğunluğunun turizmin aile bağlarını zayıflattığı konusunda hemfikirdir. Ayrıca aynı araştırmada katılımcıların büyük çoğunluğunun turizm nedeniyle toplumsal dayanışma duygularının zayıfladığı sonucu çıkmıştır. Fakat katılımcılar bu durumu geleneksel toplum yapısındaki olumsuz bir değişim olarak görmekle birlikte, aynı zamanda modern topluma özgü bireyi ve bireysel özgürlüğü ön plana çıkarması nedeniyle de olumlu bir gelişme olarak görmektedirler (Tuna, 2007: 95-97).

Ekonomik etkiye bağl1 olarak toplumda meydana gelen değişim birçok alanda kendini göstermektedir. Her şeyden önce turizm ile birlikte bir yörenin dünyaya açılması, farklı kültür, din, dil, 1rk ve mezhepten insanların yöreye getirdiği yeni kültürler ve yeni yaşam biçimlerinin, toplumda yaşayan kişileri etkilemesi kaçınılmaz bir gerçekliktir. Turizmin doğası gereği ortaya çıkan insanlar arası ilişkinin yarattığı sonuçlar, bilhassa yöre yerlisi insanları etkilemektedir. Çünkü bu ilişkide bir taraf sürekli olarak bu ilişkiye maruz kalırken, diğer taraftaki turistler tatillerini bitirdiklerinde ilişkiye de son vermiş olurlar. Zaman içerisinde özellikle turistlerin hangi ülkelerden ağırlıklı olarak geldiğgine bağlı olarak, sürekli bir kültürel etki altında kalan yöre insanı bir süre sonra maruz kaldığı kültürün etkilerini kendi yaşantısına yansıtmaya başlarlar.

Turizmin sosyal yaşam üzerine etkisi, kalabalıklaşan bir çevre, trafik, suç oranlarında artış ve artan göç ile birlikte nüfustaki ani değişimler olarak kendini gösterebilmektedir. Sosyal yaşam içinde zaman zaman şehrin taşıma kapasitesini aşan şekilde meydana gelen kalabalık ve trafik yöre sakinlerini olumsuz olarak etkileyebilmekte ve turizme karşı olumsuz tutum almalarına neden olabilmektedir. Civelek (2010: 348), turizmin sosyal yapı üzerine olumsuz etkilerinin en aza indirilebilmesi için turistik yörenin taşıma kapasitesinin aşılmaması gerektiğini belirtmektedir. 
Turistlerin aşırı serbest ve lakayt tutumlarından kaynaklanan ve bir yörede yaşayan insanların değer sistemleri ile uyuşmayan davranışları nedeniyle kültürel çatışmalar yaşanabilmektedir. Özellikle gençlerin alkol ve sigara kullanımı üzerinde kötü örnek oluşturabilecek bir ortamın yaratılmasına yol açabilmektedir.

Turizm ile birlikte kalabalıklaşmanın getirdiği diğer bir olumsuzlukta suç ile ilgilidir. Suç, hem turistlere karşı işlenen suçlar ve hem de yöre sakinlerine karşı işlenen suçlar olarak iki şekilde ortaya çıkabilmektedir. Bu suçların önemli bir kısmı ekonomik suçları kapsar. Turistler suçlular için kazançlı bir hedef durumundadır. Turistlerin rahat ve umursamaz tutumları, para ve değerli eşyalarını sergilemedeki tutumları onları kolay hedef haline getirir ve bu nedenle suç işlemek üzere yöreye gelişleri artırabilmektedir. İkincisi, turistlerin bağımlılık ve fuhuş gibi toplumun ahlaki değerlerine zarar veren suçların işlenmesi için zemin oluşabilir. Turistler kendi ülkelerinde alıștığı yaşam pratiklerini devam ettirmek için yasa dışı oluşumların ortaya çıkmasına neden olabilmektedir.

Turizm merkezlerinin demografik yapısını değiştiren en önemli olgulardan birisi de göçtür. Muğla ili özelinde bu bölgenin oldukça yoğun bir göç aldığı görülmektedir. Net göç hızına göre Türkiye'de en çok göç alan iller sırasıyla Tekirdağ, Muğla ve Antalya'dır. Nüfus sayım istatistiklerine göre, bahsedilen illerin istihdam oranları Türkiye ortalamasının 5 ila 12 puan üstü olması nedeniyle istihdam olanaklarının artması hem bu illerden dışarıya göçün az olmasına ve hem de dışarıdan göç almasına neden olmaktadır (Bahar, Bingöl, 2010: 48). Bu göç hesaplamasına mevsimlik göçler dâhil değildir. Bunun başlıca nedeni turizmin yarattığı mevsimlik istihdam etkisidir. Bu durum kentlerin bir yandan çarpık yapılaşma sorunu ile baş başa kalmasına neden olurken, öte yandan yöresel kültürel farklılıklardan kaynaklanan kültürel çatışmaların yaşanmasına da yol açabilmektedir.

$\mathrm{Bu}$ araştırmanın en önemli sınırlılıklarından birini, toplumun kültürel ve sosyal yapısına ilişkin olarak ortaya çıkan değişimlerin incelenmesinin uzun ve maliyetli bir gözleme ve araştırmaya ihtiyaç duymasıdır. Bu konuda genel ve yerel kamusal kaynakların yetersizliği nedeniyle konunun kavramsal boyutta tartışılması gerekmiştir. Toplum içinde neyin ne kadar değişim gösterdiği ve hangi unsurların bu değişimi hangi oranda etkilediğini belirlemek için, en az yirmi yıllık bir süreç içinde, yıllara göre ortaya çıkan değişimlerin ekonomik, kültürel, çevresel ve sosyal açılardan izlenmesi ve kayıt altına alınması gerekebilir. Yine de, turistik yörelerin zaman içerisinde ortaya çıkan ekonomik ve çevresel etkileri istatistiki olarak izlenebilir ve sosyal ve kültürel etkileri analitik bir düşünce perspektifi ve literatür incelemesi ile yorumlanabilir. 


\section{KAYNAKÇA}

Akis, A. (2011). The effects of mass tourism: A case study from Manavgat (Antalya - Turkey). Procedia Social and Behavioral Sciences. 19 (2011) 289-296

Ashley, C. (2000). The Impacts of Tourism on Rural Livelihoods: Namibia Experience. Overseas Development Institute. Working Paper 128.London

Aykaç, A. (2009). Yeni İşler, Yeni İşşiler: Turizm Sektöründe Emek. İletişim Yayınları. İstanbul

Biagi, B., Brandano, M. G., ve Detotto, C. (2012). The Effect of Tourism on Crime in Italy: A Dynamic Panel Approach. Vol.4, www.economics_ejournal.org/economics/discussionpapers/2012-4

Bahar, O. (2008). Muğla Turizminin Türkiye Turizmi İçin Yeri ve Önemi. Muğla Üniversitesi, Sosyal Bilimler Enstitüsü Dergisi, 21. 61-80.

Bahar, O. ve Bingöl, Korkmaz, F. (2010). Türkiye'de İç Göç Hareketlerinin İstihdam ve İşgücü Piyasalarına Etkileri. Süleyman Demirel Üniversitesi, Iktisadi ve İdari Bilimler Fakültesi Dergisi, 15 (2), 43-61.

Bahçe, A. S. (2009). Kırsal Gelişimde Kültür (Miras) Turizmi Modeli. Dumlupınar Üniversitesi, Sosyal Bilimler Dergisi. 25, 1-12.

Berber, Ş. (2003). Sosyal Değişme Katalizörü Olarak Turizm ve Etkileri. Selçuk Üniversitesi, Sosyal Bilimler Enstitüsü Dergisi, 9, 205-221.

Biçici, F. (2013). Datça Yerel Halkının Sürdürülebilir Turizm Gelişimine ve Turizm İşletmelerine Yönelik Tutumları. Seyahat ve Otel Işsletmeciliği Dergisi. 10(1), 19-36.

Brunt, P. Ve Courtney, P. (1999). Host Perceptions of Sociocultural Impacts. Annals of Tourism Research, 26 (3), 493-515.

Civelek, A. (2010). Turizmin Sosyal Yapıya ve Değiş̧meye Etkileri. Sosyal Bilimler MYO Dergisi, 13(12), 331-350

Çeken, H. (2008). Turizmin Bölgeye Katkısı Üzerine Teorik Bir İnceleme. Afyon Kocatepe Üniversitesi, I.I.B.F. Dergisi, 2, 293-306

Demirbulat, G. Ö. (2012). Turizmin Sosyal ve Kültürel Etkilerinin Turist Rehberleri Tarafindan Algılanması Üzerine Bir Araştırma: Trabzon İli Örneği. Ticaret ve Turizm Eğitim Fakültesi Dergisi, 1, 53-75

Dičevska, S. ve Simončeska, L.(2012). The Economic And Social Impact On Tourism Development, Tourism \& Hospitality Management, Conference Proceedings, 272-280

Emekli, G. (2006). Coğrafya, Kültür ve Turizm: Kültürel Turizm. Ege Coğrafya Dergisi, 15 (2006), 5159

Enemuo, O., B. Ve Oduntan, O., C. (2012). Social Impact Of Tourism Development On Host Communities Of Osun Oshogbo Sacred Grove. Journal of Humanities and Social Science, 2 (6), 30-35

GEKA (2017). Muğla İli Yatırım ve Destek Stratejisi (2017-2023). http://geka.gov.tr/Files/MU\%C4\%9ELA\%20\%C4\%B0L\%20YATIRIM\%20DESTEK\%20VE \%20TANITIM\%20STRATEJ\%C4\%B0S\%C4\%B0_27112017175636.pdf. (26.10.2018)

Giddens, A. (2008). Sosyoloji. Kırmızı Yayınları. İstanbul 
Forga, J. M. P. Ve Valiente, G., C. (2017). Cultural Change and Industrial Heritage Tourism: Material Heritage of The Industries of Food and Beverage in Catalonia (Spain). Journal of Tourism and Cultural Change. 15 (3), 265-286, http://dx.doi.org/10.1080/14766825.2015.1108327

Gürbüz, A. (2002). Turizmin Sosyal Çevreye Etkisi Üzerine Bir Araştırma. Teknoloji. 1-2, 49-59

Kaya, Ş. (2017). Turizmde Kadın Emeği. Karatahta İş Yazıları Dergisi. S. 2, 1-22

Kongar, E. (2010). Toplumsal Değişme Kuramları ve Türkiye Gerçeği. Remzi Kitabevi. İstanbul.

Kreag, G. (2001). The Impact of Toursm. Sea Grant, University of Minnesota. 13, 1-19 http://www.seagrant.umn.edu/tourism/pdfs/ImpactsTourism.pdf (10.07.2017)

Kumar, S. ve Kumar, V. (2014). Perception of Socio-Culture Impacts of Tourism: A Sociological Review. International Research Journal of Social Sciences, 3 (2), 40-43

Lane, P., J. (1988). Tourism end Social Change among the Dogon, African Arts. 21 (4), 66-69+92, 194.27.154.204 29 May1s 2017 10:09 http://about.jstor.org/terms

Mathur, A. (2011). Social Change and The Impact of Tourism on the Modern Society. International Journal of Research in Management, Economics and Commerce. 1 (2), 285-290, ISSN: 2250$057 \mathrm{X}$

Nufusu.com. https://www.nufusu.com/ilce/merkez_mugla-nufusu

Oktik, N. ve Öztürk, Ş. (2007). Sosyolojik Yapı Araştırmaları. Muğla Üniversitesi Basımevi, Muğla

Özdemir, M. A. ve Kervankıran, İ. (2011). Turizm ve Turizmin Etkileri Konusunda Yerel Halkın Yaklaşımlarının Belirlenmesi: Afyonkarahisar Örneği. Marmara Coğrafya Dergisi, 24, 1-25

Özel, Ç. H. (2014). Turizmin Sosyo-Kültürel Boyutta Ortaya Çıkardığı Etkilerin İncelenmesi: Marmaris Örneği. Dumlupınar Üniversitesi Sosyal bilimler Dergisi. 42, 57-68

SEGE-2011. (2013). İllerin ve Bölgelerin Sosyo-Ekonomik Gelişmişlik Sıralaması Araştırması. T.C. Kalkınma Bakanlığı, Bölgesel Kalkınma ve Yapısal Uyum Genel Müdürlüğü

Şit, M. (2016). Türkiye'de Turizm Sektörünün İstihdama Katkısı. Akademik Yaklaşımlar Dergisi. (7)1, $101-117$

Tuna, M. (2007). Turizm, Çevre ve Toplum. Detay Yayıncılık. Ankara

Urry, J. (1988). Cultural Change and Contemporary Holiday-making. Theory, Culture \& Society. 5(1988), 35-55, http://journals.sagepub.com/doi/ pdf/10.1177/026327688005001003 (11.07.2017)

Wallersteın, I. (2010). Modern Dünya Sistemi. (Çev. Boyacı, L.). İstanbul: Yarın Yayınları

Yerelnet- Yerel Yönetimler Portal1. www.yerelnet.org.tr

Yıldız, E. ve Çalışkan, U. (2018). Turizme Yakın Ama Turizmden Uzak Yerel Halkın Turizme Bakışı: Muğla Menteşe İlçesi Örneği. Trakya Üniversitesi Sosyal Bilimler Dergisi. 20(2), 223-243 